\title{
An Ode to ODA against all Odds? A Novel Game-Theoretical and Empirical Reappraisal of the Terrorism-Aid Nexus
}

\author{
Elkhan Richard Sadik-Zada ${ }^{1,2,3,4}$
}

Accepted: 4 May 2021 / Published online: 23 June 2021

(C) The Author(s) 2021

\begin{abstract}
The present inquiry revisits the influence of the fourth religious wave of modern terrorism on the allocation of official development assistance (ODA). The theoretical framework is predicated first on comprehensive review of the pertinent literature on the nexus between political instability and foreign aid, augmented by the assessment of Central Intelligence Agency declassified documents and Congressional Service Reports. Based on the systematic review of the sources, the study puts forward a novel dynamic differential game theory model, which enables derivation of the scenarios for foreign aid allocation. The study finds that despite dominance of geopolitical and/or commercial interests in the allocation of aid, high incidence of terrorist attacks does not lead to less development aid, but rather catalyzes it. Subsequent empirical analysis of a dataset with 121 developing and transition economies spanning between 1970 and 2016 reveals that terrorism incidents, level of political rights, and the War on Terror had a statistically significant positive long-run and negative short-run effect on the level of foreign aid commitment of the Organisation for Economic Co-Operation and Development member states. The growth rate of foreign aid in the developing countries with a predominantly Muslim population has been systematically 0.1 to 0.85 percent greater than in non-Muslim countries.
\end{abstract}

Supplementary Information The online version contains supplementary material available at https://doi.org/10.1007/s11293-021-09710-9.

Elkhan Richard Sadik-Zada

elkhan.r.sadik-zada@ruhr-uni-bochum.de

1 Institute of Development Research and Development, Ruhr University, Bochum, Germany

2 Centre Environment, Resources and Energy Economics, Faculty of Management and Economics, Ruhr-University, Bochum, Germany

3 Center for Studies On European Economy, Azerbaijan State University of Economics (UNEC), Baku, Azerbaijan

4 CED - Center for Economic Development and Social Change, Naples, Italy 
Subsequent assessment of the security bias in the allocation of aid indicates that resecuritization of aid since 1998 has led to weak diversion of aid commitment from areas with fewer terrorism incidents to jurisdictions with a greater frequency of terrorist attacks.

Keywords Official development assistance $\cdot$ Terrorism incidents · Securitization · War on Terror · Pooled mean group · Nonparametric panel approach · Open-loop Nash equilibrium

JEL $\quad \mathrm{D} 72 \cdot \mathrm{D} 73 \cdot \mathrm{L} 72 \cdot \mathrm{O} 13$

\section{Introduction}

A sizeable body of empirical literature indicates that despite the officially stated goal of socioeconomic development, geopolitical and commercial interests of donor states have been the major driver of foreign aid action during the seven decades after World War II (Apodaca 2017; Beenstock 1980; Dreher and Fuchs, 2011; McConnon 2019; Mosley 1985). The Cold War was not confined to regional confrontation between countries of the Warszawa Pact and the North Atlantic Treaty Organization (NATO). Communist and capitalist systems were in global competition over binding Third World countries to their orbit of influence (Younas 2008). Implied was pursuit of proliferation of the respective forms of governance and ideologies in developing areas. Declassified Central Intelligence Agency (CIA) reports from the 1980s, contemporary Congressional Research Service reports, and academic sources indicate that dominance of geopolitical calculus in determining the geography and magnitude of aid has been even more pronounced in the case of foreign aid policies of emerging donor nations, and especially member states of the Gulf Cooperation Council (CIA 1975, 1984; Blanchard and Prados, 2007).

Political instability in developing countries is deemed an opportunity to enhance influence or an instrument for protection of existing positions in regions of pivotal geopolitical importance for the national security interests of the donor states (Khasbulatov 1998). Unfortunately, the former Soviet Union (FSU), by supporting leftist terrorist organizations, and the U.S., by supporting groups like Mujahidin in Afghanistan or Contras in Latin America, tried to increase their geopolitical positions in unstable regions. These types of policies have been on the decline since the FSU collapse and especially 9/11. Nevertheless, there are still some forces in the oil-rich states that continue financing religiously-motivated terrorist organizations (Freeman and Ruehsen, 2013; Lee 2016).

With the collapse of the Union of Soviet Socialist Republics (USSR) and consequent end of the Cold War, the world entered a new phase of international 
relations. The absence of the Communist threat led to dramatic shrinkage of foreign aid between the early and late 1990s (Abadie, 2006; Bandyopadhyay et al., 2011; Drakos and Gofas, 2006).

The emergence of the fourth religious wave of international terrorism was triggered by three events. These are the Munich bus attack in 1970, the massacre during the 1972 Summer Olympics, and the 1979 Islamic Revolution in Iran. ${ }^{1}$ This wave developed into a truly globally omnipresent phenomenon in the aftermath of the 9/11 terrorist attacks. 9/11 led to a resurgence of security issues as the central driver of official development assistance (ODA) (Gaibulliev and Sandler, 2019; Gupta 2011; Rapoport 2004). Despite substantial reforms in a number of Middle Eastern and North African states in the aftermath of the Arab Spring, religiously-motivated violence is not losing momentum and continues to shape international politics. Despite the prognosis of Rapoport (2004), it seems now that the fourth wave is not following his prediction that the fourth wave would end by the year 2025 . The risk of violent religiously-motivated terrorism could potentially perpetuate for a much longer time (Rapoport 2004; Walls 2017).

The present inquiry re-addresses the following research questions: 1 . Do terrorism incidents affect international aid action? (assessment of causality and direction); 2. What is the impact of terrorism on the magnitude of ODA? (assessment of the strength of the relationship between the frequency of terrorism incidents and the magnitude of ODA); 3. What is the impact of the War on Terror on ODA? (assessment of the securitization conjecture); 4 . What is the relationship between underdevelopment and the inflow of ODA to developing and transition countries?; 5. Did securitization of aid lead to less aid for jurisdictions with low terrorism incident levels?; 6 . What is the relationship between the level of democracy in recipient countries and the magnitude of foreign aid?; 7. Is there a relationship between a predominantly Muslim population and the magnitude of aid?

This paper contributes to the literature on the terrorism-foreign aid nexus in three ways. First, it augments the systematic literature on drivers of foreign aid action by scrutinizing declassified CIA records and Congressional Reports. Second, based on the literature review, the study proposes a differential game-theoretical model of aid budget distribution among targets to facilitate the socioeconomic development of recipients, geopolitical targets, and commercial interests of donor states. The third contribution of this paper is empirical. Based on the proposed theoretical model, the study revisits the terrorism-aid nexus using second-generation parametric panel cointegration techniques and nonparametric panel models with fixed effects and varying coefficients. The purpose of this inquiry is to overcome the methodological shortcomings of previous studies and intervene convincingly in the discussion on the relationship between terrorism incidents and foreign aid policies.

\footnotetext{
1 According to Rapoport (2004), prior to the fourth wave, there were three waves of modern terrorism. These are an Anarchist wave between the French Revolution and the end of the First World War (18791919); an Anti-Colonial wave between the 1920s and 1960s; and the New Left wave between the 1960s and 1980s.
} 


\section{Review of the Literature and Achieve Records}

\section{Determinants of Aid Allocation}

A wealth of empirical literature indicates that despite fundamental changes in the priorities of foreign policy in the early 1960s, early 1990s, and in the aftermath of 9/11, the issues of donor national security have played an important role in donor decisions on the geography and magnitude of ODA (Beenstock 1980; Bird 1999; Boutton 2016; Hamilton 1982; Lancaster 2006; Maizels and Nissanke, 1984; McKinley and Little, 1979; Pupavac 2010; Sörensen and Söderbaum, 2012). Based on bilateral aid data, Alesina and Dollar (2000) found that allocation of bilateral aid is mostly motivated by political and strategic considerations of donors. Further, they found that colonial ties and political alliances also determine the allocation of ODA. This is in line with the findings of Dudley and Montmarquette (1976), which revealed that during the first two decades in the aftermath of World War II, ODA was driven by international security issues related to the Cold War and colonial ties of donor nations. Stone (2010) showed that, especially for the U.S. and France, geopolitical interests played a decisive role in the allocation of ODA. For continental Europe and Japan, geopolitical influence was also a substantial, but less pronounced, driver of ODA compared to the U.S. and France. Based on a more comprehensive panel dataset for 22 Development Assistance Committee (DAC) donors and 22 recipient countries for the time frame between 1980 and 2004, Hoeffler and Outram (2011) found that donors' geostrategic and commercial interests dominated aid allocation decisions of nations with an advanced level of economic development.

\section{Retrospective Assessment of the Declassified CIA-Records ${ }^{2}$}

In the U.S., the nexus between foreign aid and geopolitical influence has been legally anchored in the Foreign Assistance Act of 1961 which proclaimed assistance to maintain the internal security of countries that are favorable to the U.S. as an official goal of U.S. aid policies (CIA 1961; Rennack and Chesser, 2011). According to different CIA reports released since 1965, maintaining a stable balance of military power between East and West was the major goal of U.S. foreign aid action since the inception of the Marshall Plan (CIA 1965, 1970, 1974, 1976, 1985a, 1985b, 1986). The reports indicate the importance of aid action to enhance sustainable economic growth in economically less developed countries to encourage the growth of politically resilient democracies. The proliferation of this kind of society was deemed the best remedy against the Communist threat. Nevertheless, "the question

\footnotetext{
${ }^{2}$ Based on Executive Order 13526, the classified documents and reports of the CIA have to be declassified and made publicly available. This implies declassification of a huge number of documents since the end of the Second World War. This study makes use of this archive of records for the derivation of the theoretical framework.
} 
at issue, both for the Free World as well as the Soviet Block, is not whether growth will occur, but what political forms it will give rise to." (CIA, 1968, p. 5).

In his contribution to the New York Times Magazine in 1965, James Fulbright excoriated American foreign aid on a variety of grounds. The central critique was related to the shortsightedness of aid policies:

"The United States nonetheless maintains aid programs in about 90 countries.

Few of these contribute appreciably to economic development or to our security. Many are token programs designed to maintain an American "presence", which I take to be a euphemism for the exertion of one form or another of political leverage." (Fulbright, 1965, p. 3).

Furthermore, the author suggested the separation of long-term development assistance from geopolitically motivated short-term assistance (Fulbright 1965). To this end, he proposed handling economic aid as a completely international affair, more multilateral and less dependent on U.S. homeland security. Frank Getlein (1973) in his famous contribution to the Washington Star deemed exploiting development cooperation for political reasons by the CIA as an inappropriate business as usual. Further, he refered to the findings of Paddock and Paddock (1973), which showed that the success stories of U.S. aid policy in Central and Latin America were in reality a failure (Getlein 1973). As a remedy, Paddock and Paddock (1973) also recommended putting money in the hands of unilateral organizations, which are more dominated by development targets than bilateral agencies. A former member of the U.S. House of Representatives and a former member of the U.S. Homeland Security Advisory Council, Lee Hamilton, criticized the imbalance in U.S. foreign aid epitomized in the dominance of Egypt and Israel in U.S. aid disbursement. He argued that this kind of uneven allocation of aid is not in line with the proclaimed targets of global poverty alleviation and economic development in a wide range of developing countries. He advised rethinking the distribution and adjusting it to meet development goals in developing areas (Hamilton 1982).

\section{End of the Cold War and Foreign Aid}

The end of the Cold War led to a substantial reduction in geostrategic security threats for the West and its allies (Bird 1999). Hence, the volume of ODA dropped from 62.7 billion USD in 1989 to 34.7 billion USD in 1996. The sharpest decline in aid was owed to the reduction in U.S. aid. Canada, Germany, Italy, Japan, and the Netherlands followed this trend. However, despite the disappearance of the risk of a large-scale nuclear war, the fall of the USSR triggered a new wave of armed conflicts, civil wars, state fragility, and religious radicalization in developing and transition countries. The post-Cold War world witnessed the emergence of 58 persistent armed conflicts in 46 locations (Picciotto 2007). The U.S. embassy bombings of August 1998 and 9/11 made clear that failed states and concomitant underdevelopment provide fertile soil for the proliferation of international terrorism (McConnon 2019). 
The attacks of $9 / 11$ demonstrated once more with clarity the enormous and destructive potential of international terrorism networks that emanate from the least developed areas for the homeland security of economically advanced nations. This led to a paradigm shift in international development policies, often dubbed as securitization of development policies (Duffield 2002, 2005; Pupavac 2010). Since the mid-2000s, development agencies refer explicitly to ODA as a cornerstone of their strategy to fight terrorism and violent extremism (Brown et al., 2011; Stern and Öjendal, 2010).

In reaction to 9/11, in March 2002, George Bush announced the most rapid increase in U.S. foreign aid since initiation of the Marshall Plan and put aid policies in the first tier of U.S. foreign policy. In 2005, U.S. aid was at the highest level in U.S. history. This holds even if aid for the reconstruction of Afghanistan, Iraq, and Pakistan is subtracted from the total amount of aid for 2005 (Lancaster 2006). Similar tendencies were also stark in British, German, Canadian, French, and Japanese foreign aid policies (Oxfam 2011; Tuman et al., 2017).

\section{Differential Game Model of the Allocation of Foreign Aid}

\section{Two-Department Open-Loop Nash Equilibrium Scenario}

This subsection presents a dynamic game-theoretical model of aid allocation. Based on evidence from the literature review, there are two essential priorities in the allocation of aid. Homeland security and geopolitical interests are first, and commercial interests are second. Furthermore, it is assumed that a fixed share of the gross domestic product (GDP), $\psi \in(0, s)$, of a donor country is annually spent on development aid. If the GDP of the donor country is denoted by $Y_{d}(t)$, then the donor spends in absolute terms $A(t)=\psi Y_{d}(t)$ on foreign aid. It is assumed that foreign aid reimbursement is managed by a specialized aid agency. This agency is dominated by two groups organized in two separate departments. The first department focuses on the issues of homeland security and geopolitical issues (Player 1). The second department represents the commercial interests of the donor economy (Player 2). The share of the aid budget $u_{1}(t) \in(l, h)$ is spent on security and geostrategic targets whereby $0<l<h<1 . u_{2}(t) \in[0, \theta]$ is the proportion of the remainder spent on projects which are entirely dedicated to long-term socioeconomic development. The remainder, i.e., $\left[1-u_{2}(t)\right]$, is spent on projects that focus on the commercial interests of donors seeking markets or resources. Based on these assumptions, the basic technical relationships of the foreign aid system can be formulated as follows:

Gross Foreign Aid Budget $\equiv A(t)$,

Donor's Security and Geopolitics Budget $\equiv A(t) u_{1}(t)$,

Donor's Commercial Interests Budget $=A(t)\left(1-u_{1}(t)\right)\left(1-u_{2}(t)\right) ;$ and

Net Development Aid $\equiv \dot{A}=A(t)\left(1-u_{1}(t)\right) u_{2}(t)$.

Both departments try to maximize their budgets. Following Hoel (1978), a linear relationship is assumed between the size of the budget of the respective team and its utility. Both Player 1 and Player 2 discount their utilities. 
The utility function of the Security and Geopolitics Department, i.e., Player 1 , is determined by the integral of the discounted revenue flows as follows: $J_{1}=\int_{0}^{T} e^{-\rho_{1} t}\left[A(t) u_{1}(t)\right] d t$. The utility function of the Commerce Department, i.e., Player 2 , squares with the following equation: $J_{2}=\int_{0}^{T} e^{-\rho_{2} t}\left[A(t)\left(1-u_{1}(t)\right)\right.$ $\left.\left(1-u_{1}(t)\right)\left(1-u_{2}(t)\right)\right] d t$.

To determine the optimal pathways of the control variables of Player $1, u_{1}(t)$, and Player 2, $u_{2}(t)$, the Hamiltonian functions must be set. The current and future utility of Player 1 can be expressed via the Hamiltonian function, $H_{1}$, formulated in Eq. 7. The optimal path for $u_{1}(t)$ (given $u_{2}(t)$ ) will maximize $H_{1}$ at every instant of time (Dorfman 1969) is : $H_{1}=e^{-\rho_{1} t}\left[A(t) u_{1}(t)\right]+\lambda_{1}(t)\left[A(t)\left(1-u_{1}(t)\right) u_{2}(t)\right]$, whereby $\lambda_{1}$ is a co-state variable indicating the shadow value of the marginal increase of development aid for Player 1 . The possible reason for the positive valuation of development by the security team is that economic development reinforces security aid by consolidating the social basis for the emerging geopolitical influence of donor countries.

According to Pontryagin's maximum principle, the co-state variable $\lambda_{1}$ must satisfy the following condition:

$$
\dot{\lambda}_{1}=-\frac{\partial H_{1}}{\partial A}=-e^{-\rho_{1} t} u_{1}(t)-\lambda_{1}(t) \psi\left(1-u_{1}(t)\right) u_{2}(t) .
$$

In this problem, $\dot{\lambda}_{1}(t)$ represents the change in the marginal contribution of purely socioeconomic development aid to the utility of Player 1 in terms of the extension of geopolitical influence at time $t$. Since Player 1 does not look beyond the planning horizon of $T$, the marginal value of an investment at the end of the program is zero. Hence, the transversality condition is commensurate with $\lambda_{1}(T)=0$.

The choice of the value of $u_{1}(t)$ from the possible range of $[l, h]$ depends upon the value of the product of the co-state variable, $\lambda_{1}(t)$, and the control variable of the commerce team, $u_{2}(t)$. The optimality conditions of Pontryagin type for Nash equilibria are given by: $u_{1}=\left\{\begin{array}{l}l \\ h\end{array}\right\}$ if $\lambda_{1} u_{2} e^{\rho_{1} t}\left\{\begin{array}{l}>1 \\ <1\end{array}\right\}$.

The Hamiltonian function of Player 2, i.e., the Commerce Department, has the following form:

$$
H_{2}=e^{-\rho_{1} t}\left[A(t)\left(1-u_{1}(t)\right)\left(1-u_{2}(t)\right)\right]+\lambda_{2}\left[A(t)\left(1-u_{1}(t)\right) u_{2}(t)\right] .
$$

The co-state variable, $\lambda_{2}(t)$, is the marginal contribution of development commitment to the Commerce Department's utility. The path of $\lambda_{2}$ is determined by the differential:

$$
\begin{aligned}
\dot{\lambda}_{2} & =-\frac{\partial H_{2}}{\partial A}=-e^{-\rho_{2} t}\left[\left(1-u_{1}(t)\right)\left(1-u_{2}(t)\right)\right]-\lambda_{2}\left[\left(1-u_{1}(t)\right) u_{2}(t)\right] \\
& =-\left(1-u_{1}(t)\right)\left(e^{-\rho_{2} t}\left(1-u_{2}(t)\right)+\lambda_{2} u_{2}(t)\right) \\
& =-\left(1-u_{1}(t)\right)\left(e^{-\rho_{2} t}-u_{2}(t)\left(\lambda_{2}-1\right)\right) .
\end{aligned}
$$

$H_{2}$ is maximized by the values of $u_{2}(t)$ that satisfy the following conditions: $u_{2}=\left\{\begin{array}{l}0 \\ 1\end{array}\right\}$ if $\lambda_{2} e^{\rho_{2} t}\left\{\begin{array}{c}<1 \\ >1\end{array}\right\} u_{2}=\left\{\begin{array}{l}0 \\ 1\end{array}\right\}$ if $\lambda_{2} e^{\rho_{2} t}\left\{\begin{array}{l}<1 \\ <1\end{array}\right\}$. 
Without discounting, the optimality condition would be $u_{2}=\left\{\begin{array}{l}0 \\ 1\end{array}\right\}$ if $\lambda_{2}\left\{\begin{array}{c}<1 \\ >1\end{array}\right\}$.

Hence, four possible scenarios are in line with the optimality conditions:

I. $u_{1}=l ; u_{2}=0$; if $\lambda_{1} u_{2} e^{\rho_{1} t}>1$ and $\lambda_{2} e^{\rho_{2} t}<1$ (unfeasible scenario)

II. $u_{1}=h ; u_{2}=0$; if $\lambda_{1} u_{2} e^{\rho_{1} t}<1$ and $\lambda_{2} e^{\rho_{2} t}<1$ (nondevelopment security mode)

III. $u_{1}=l ; u_{2}=1$; if $\lambda_{1} u_{2} e^{\rho_{1} t}>1$ and $\lambda_{2} e^{\rho_{2} t}>1$ (development mode)

IV. $u_{1}=h ; u_{2}=1$; if $\lambda_{1} u_{2} e^{\rho_{1} t}<1$ and $\lambda_{2} e^{\rho_{2} t}>1$ (security and development mode)

It is obvious from inspection that scenario $\mathrm{I}$ is not feasible because $u_{2}=0$ and $\lambda_{1} u_{2} e^{\rho_{1} t}>1$ are mutually incompatible. This leaves only three scenarios to be examined.

An analysis of this kind of problem starts with scrutiny of the end phase rather than the initial phase (Lancaster 1973). There is a boundary condition $\lambda_{2} e^{\rho_{2} t}=0$, and $\lambda_{2}$ must be a continuous function of time. Thus, $\lambda_{2} e^{\rho_{2} t}<1$ must hold at the end and for some period before the end. Let $\bar{t}$ denote the beginning of the period for which $\lambda_{2} e^{\rho_{2} t}<1$ (if $\lambda_{2} e^{\rho_{2} t}<1$ everywhere, then $\bar{t}=0$ ). In this final phase, combination II holds. Now, the following equations are produced by inserting the relevant values of the control variables in the differential Eqs. (1), (2), and (4):

$$
\begin{gathered}
\dot{A}=0, A(t)=A(\bar{t}) \forall t \in[\bar{t}, T], \\
\dot{\lambda}_{1}=-e^{-\rho_{1} t} h, \lambda_{1}(t)=\lambda_{1}(\bar{t})-e^{-\rho_{1} t} h(t-\bar{t}) \forall t \in[\bar{t}, T], \text { and } \\
\dot{\lambda}_{2}=-e^{-\rho_{2} t}(1-h), \lambda_{2}(t)=\lambda_{2}(\bar{t})-e^{-\rho_{2} t}(1-h)(t-\bar{t}) \forall t \in[\bar{t}, T] .
\end{gathered}
$$

The last two equations show that both co-state variables decrease linearly in the final phase. This and the transversality condition, $\lambda_{2}(T)=0$, enable the calculation of $\bar{t}$. This is the time point at which $\lambda_{2}(\bar{t})=1$. To this end, $t$ in Eq. (3) is replaced by $T$, and to make use of the transversality condition, $\lambda_{2}(T)$ is replaced by zero.

$$
0=1-e^{-\rho_{2} t}(1-h)(T-\bar{t}) \rightarrow e^{-\rho_{2} t}(1-h)(T-\bar{t})=1 \rightarrow(T-\bar{t})=\frac{1}{e^{-\rho_{2} t}(1-h)} \rightarrow \bar{t}=T-\frac{1}{e^{-\rho_{2} t}(1-h)} .
$$

Given $T>\frac{1}{e^{-\rho_{1} t}(1-h)}$, the system enters its final phase at time $\bar{t}$ given by Eq. 4 .

Before $\bar{t}, \lambda_{2}(t)>1$. Thus, this phase will be defined by combination III or IV. Since in both these combinations $u_{2}=1$, in this phase $\lambda_{1} u_{2}=\lambda_{1}$, and thus the value of $u_{1}$ depends on whether $\lambda_{1}$ is greater or less than unity. Going back to the final phase, $\lambda_{1}(T)=0$ and $\lambda_{1}$ declines at the time rate $e^{-\rho_{1} t} h$ during this phase. At $\bar{t}$, therefore, the value of $\lambda_{1}$ is given by $\lambda_{1}(\bar{t})=e^{-\rho_{1} t} h(T-\bar{t})=\frac{h}{1-h}$. Now, $h$ is the maximum ratio of security-related foreign aid to the total aid budget, and is assumed to be greater than 0.5 . Hence, $\frac{h}{1-h}>1$ and $\lambda_{1}(\bar{t})>1$. This implies that the penultimate phase will be characterized by combination III $\left(u_{1}=l, u_{2}=1\right)$. Insertion of the control variable values into the differential equations for $\lambda_{1}(t)$ and $\lambda_{2}(t)$ shows that both co-state variables are greater than zero. Thus, there is no phase before that represented by combination III and the solution consists of two phases, commencing with III, then switching to II at time $\bar{t}$. In other words, the security department spends minimally and capitalists accumulate up to the time $\bar{t}$. Then, both groups switch to maximum levels 
of expenditures to assure homeland security's and donor's economic interests overseas.

\section{Interpretation of the Open Loop Nash Solution}

The model implies that during the first phase of development, cooperation within the terrorism-or war-ravaged regions, the donors devote a minimum share of the aid budget to assure a basic level of security. The rest of the aid budget is dedicated to purely developmental projects. This phase ends after assuring the necessary level of security, which prevents social unrest and enables economic recovery. The overwhelming share of aid consists of humanitarian aid and aid for the development of basic infrastructure. The beginning of the second phase corresponds with positive growth rates and political stabilization. At this stage, the aid budget is divided between geopolitical and commercial expenditures. Geopolitical expenditures assure the steady or growing political influence within the hypothetical developing country. Commercial expenditures assure resource and market seeking. Hence, during the second phase, foreign aid, in its essence, does not fulfill the development aspiration of ODA, but rather investment in the improvement of foreign geopolitical and economic interests of donor countries.

During the first phase, it is not possible to enhance any lasting geopolitical or commercial interest. In terms of political stability, it is a kind of fragility phase. Hence, both departments direct their available resources toward recovery of basic statehood and socioeconomic stabilization. Hence, during the first phase, there is plenty of aid for economic recovery and promotion of basic institutions to assure political stability. These institutions are the prerequisite for proliferation of the donor's geopolitical dominance in the aftermath of state fragility. During the second phase, foreign aid is dedicated solely to the enhancement of commercial interests and geopolitical project costs for the enhancement of geopolitical influence within developing areas.

Hence, if it is hypothesized that terrorism incidents are a measure of political fragility, then following the proposed differential game model, a positive relationship between terrorism incidents and foreign aid action during political fragility and initial post-conflict recovery phases is conceivable.

\section{Empirical Methodology}

To the best of the author's knowledge, with a panel data set of 121 developing and transition countries (N) and 46 time periods (T) spanning between 1970 and 2016, this is the largest dataset on the nexus between ODA and terrorism incidents regarding both $\mathrm{N}$ and $\mathrm{T}$. The countries in the dataset are listed in Online Supplemental Appendix Table 1. The data series is described in Online Supplemental Appendix Table 2.

The survey applies innovative panel techniques that accommodate structural breaks, non-stationarity, panel heterogeneity, endogeneity, cross-sectional dependence, the direction of the causality, and nonlinearities. Both long- and short-run 
relationships were analyzed between terrorism incidents and ODA of the principal provider of ODA, the member states of the Organization of Economic Cooperation and Development (OECD). Data on the frequency of country-specific terrorism incidents was provided by the Global Terrorism Database (Miller et al., 2020).

Conventional panel estimation techniques, such as fixed effects, random effects, and generalized method of moments (GMM) estimators, have restricted capability in correcting heterogeneity, endogeneity, mixed stationarity, and cross-sectional dependence issues. To account for these econometric problems, this study employed a cross-sectionally augmented mean group (MG) and pooled mean group (PMG) (Pesaran and Smith, 1995). PMG yields homogenous long-run coefficients and also allows for country-specific intercepts, short-run coefficients, and error variances. MG estimators estimate country-specific long- and short-term coefficients (Pesaran et al., 1999; Chudik and Pesaran, 2015; Mohaddes and Raissi, 2017). Because the underlying dataset has a relatively large $\mathrm{N}$ and $\mathrm{T}$, the asymptotic characteristic of the dataset is in line with that of (P)MG estimators. MG tolerates differences in long-term slopes, short-term responsiveness, and intercepts. Like fixed-and random-effects estimators, MG also ignores the issue of cross-sectional dependence (CSD). CSD arises due to omitted common shocks, spatial effects, or interactions within socioeconomic networks (Chudik and Pesaran, 2015). Hence, the study employed cross-sectionally augmented (CS) and common correlated effects autoregressive distributed lag (ARDL), MG, and PMG estimators.

To assess the robustness of the $\mathrm{P}(\mathrm{MG})$ estimators, the study employed Pedroni's group mean fully modified ordinary least squares OLS (FMOLS) estimator, which exploits the super consistency properties of the cointegrated I(1) series (Nielsen 2007; Pedroni 2001; Cavalcanti 2011). This property handles the endogeneity and omitted variable problem (Narayan and Narayan, 2004).

\section{Nonparametric Approach}

The shortcoming of these parametric estimators is their assumption of a linear relationship between terrorism incidents and foreign aid. However, most phenomena in the social sciences are nonlinear and path-dependent. Hence, despite tendentious correctness, the results of the linear estimations do not reveal the real functional form of the relationship between terrorism incidents and foreign aid action. To address econometric misspecification bias, the study also employed non-parametric trending models, which let the data determine the specific functional form of the nexus between independent and dependent variables. This methodology is superior to parametric linear and polynomial models and less prone to omitted variable bias (Lee and Robinson, 2015). The paper at hand employed the non-parametric time-varying coefficient panel data model with fixed effects suggested in Li et al. (2011). For detailed econometric specification of the nonparametric model, see Online Supplemental Appendix Table 3. 


\section{Discussion of the Results}

In the first step of the causality analysis, the Westerlund test for cointegration indicates that both the quantity of foreign aid and the grants component are cointegrated with the number of terrorism incidents. This confirms that there is a longterm relationship between terrorism incidents and foreign aid-indicators (Online Supplemental Appendix Table 4). After confirming the long-run relationship between terrorism incidents and aid, the study employed an error correction model (ECM) with common factors. This procedure substantiated the unidirectional relationship between aid and terrorism incidents, whereby only the quantity of terrorism incidents had a statistically significant impact on the level of ODA, and not vice versa (Online Supplemental Appendix Table 5). To assess the robustness of this result, the study also employed the Toda-Yamamoto Granger Non-Causality Test (Toda and Yamamoto, 1995). Test statistics are available in Online Supplemental Appendix Table 6. The test statistics strongly confirm that terrorism incidents cause variations in ODA.

\section{Re-Assessment of the Determinants of ODA}

The results of the parametric estimators are presented in Table 1. All the estimations indicate a robust and statistically significant positive long-run impact of terrorism incidents on the level of foreign aid. A one percent increase in terrorism incidents leads to a $0.042-0.168$ percent increase in ODA. The short-run effect of terrorism on ODA is statistically significant but negative. The values of the elasticity range between -0.026 and -0.349 . These findings imply that increasing terrorist activities led to a short-term decline in aid. This could be the result of the time required for reassessment of the aid strategy in the respective jurisdiction. Nevertheless, in the long run, terrorism leads to a perceivable increase in ODA.

The study finds that in the short run, the War on Terror led to an 8.7-10.35 percent decrease in ODA. However, in the long run, the War on Terror phase led to a 24.5-35.6 percent increase in foreign aid.

The level of political freedoms, polity2, had a statistically significant positive impact on the level of aid. An increase in the polity 2 index, i.e., the level of political rights, by one unit led to 2.7 percent more ODA for the recipient country. The shortterm increase in the level of political freedoms, however, corresponds with a negative effect on ODA. An increase in political rights by one unit led to a 2.5 percent decrease in ODA in the short run.

The scrutinized parametric estimators in Table 1 indicate a linear best fit, which is of course a valid identifier of the long- and short-term relationships. Nevertheless, these linear parametric estimators neglect the changing strength of the relationship in the long run. To account for this limitation, the study also employed the nonparametric fixed effects estimator with changing coefficients. The estimator indicates that the responsiveness of foreign aid to the level of per capita income declined between 1970 and 2000, whereby the coefficient was positive between 1970 and 1979 (Fig. 1). This implies that in the early 1970s, a one percent increase in average 


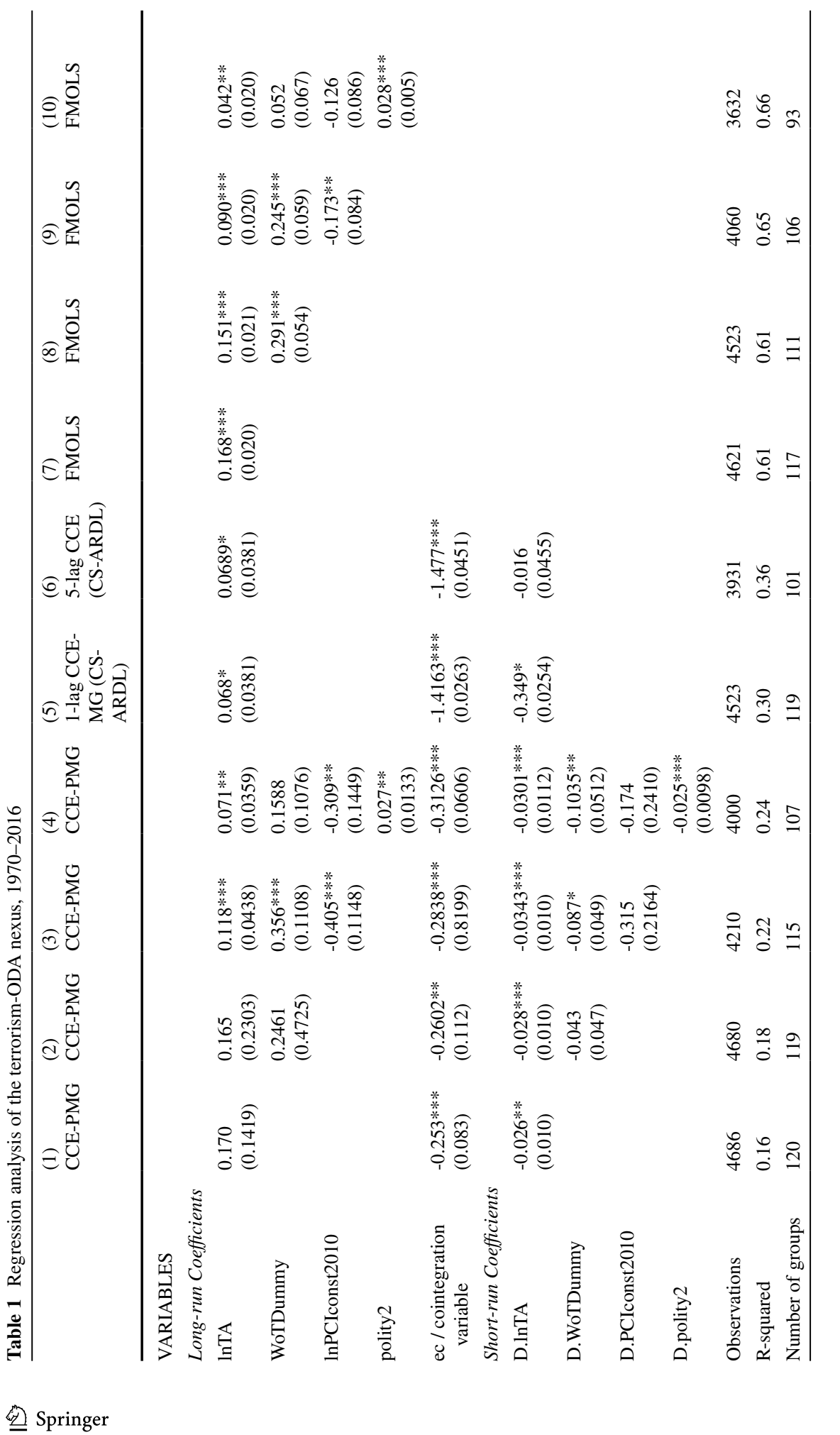




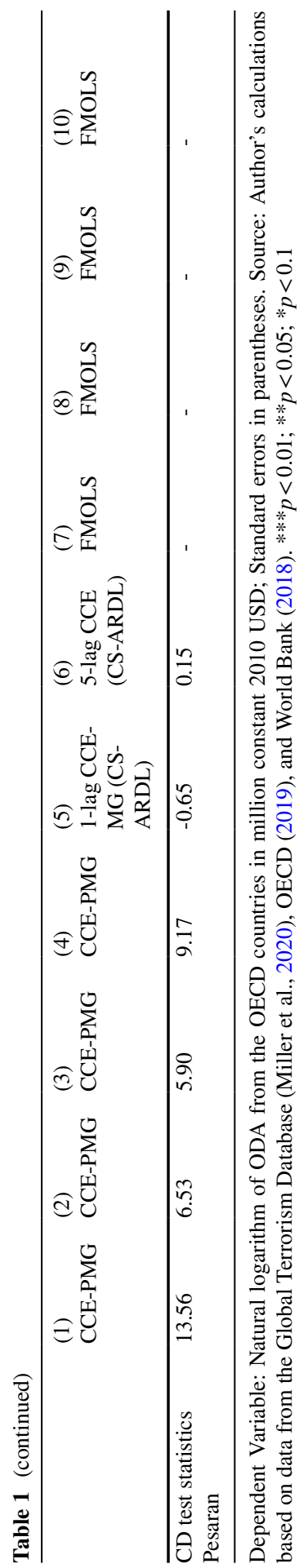




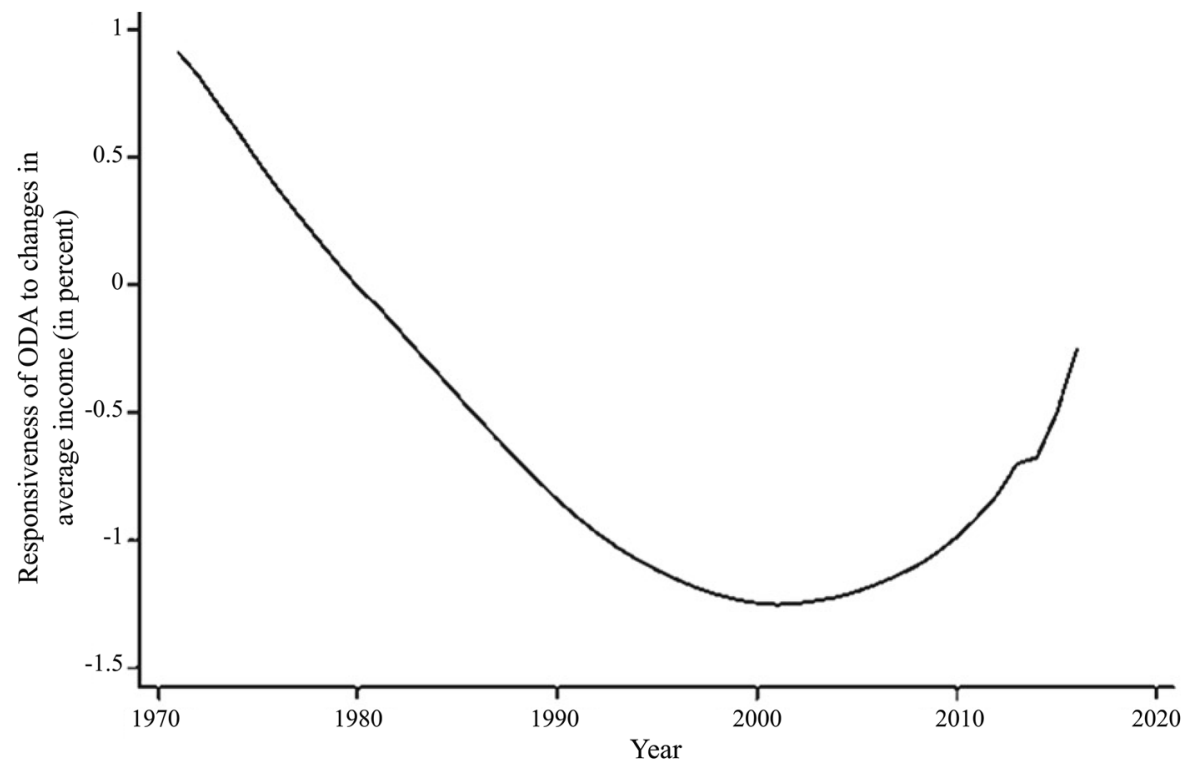

Fig. 1 Per capita Income and Foreign Aid, 1970-2016. Source: Author's calculations based on data from the World Bank (2018) and OECD (2019)

income in the developing areas led to approximately a 0.9 percent increase in aid. In 1979, responsiveness fell to zero and continued falling uninterruptedly until it reached -1.3 percent in 2000 .

This implies that between 1979 and 2000, increasing (decreasing) levels of average income in developing countries caused less (more) aid allocation in the respective jurisdictions, whereby responsiveness sank from 0 to -1.3 percent between 1979 and 2000. Between 2001 and 2016, the strength of the negative association between average income and foreign aid commitment steadily decreased. In 2016, one percent more (less) average income led to 0.25 percent less (more) aid commitment in developing areas. The contraction of the coefficient could be the result of the resecuritization of aid since $9 / 11$.

A further nonparametric estimation is related to the strength of the relationship between terrorism incidents and the geography of foreign aid. The results of the bivariate nonparametric estimator with fixed effects are illustrated in Fig. 2. Between 1970 and 1985, the responsiveness of aid to terrorism incidents was positive. Between 1985 and 2000, the responsiveness ranged between 0 and 0.1 percent. Since 1993, the responsiveness has increased continuously and since 2000, is in the positive range. 


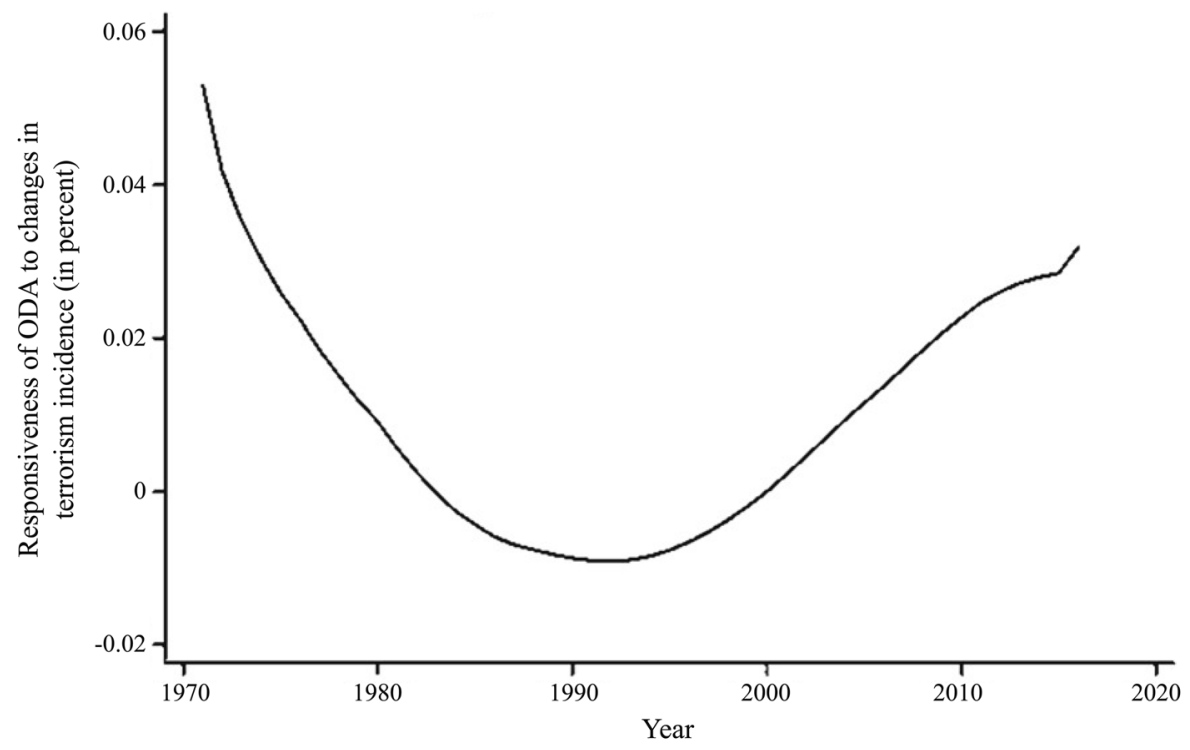

Fig. 2 Terrorism Incidents and Foreign Aid, 1970-2016. Source: Author's calculations based on data from Global Terrorism Database (Miller et al., 2020) and OECD (2019).

\section{Islam and Allocation of Aid since the Onset of the Fourth Wave}

As already mentioned, the time interval of the present inquiry encompasses the fourth wave of modern terrorism, which has continued since the late 1970s and is religiously motivated (Rapoport 2004). Due to the dominance of Islamic terrorism within the fourth wave, the study tried to analyze whether the predominance of Muslims in the total population influenced the geography of aid distribution.

In the framework of the nonparametric estimation, the study found that since the 1980s, the predominance of the Muslim population corresponds with greater growth of ODA. Since 2000, being a Muslim country led on average to 0.8 percent more aid (Fig. 3). The impact of this variable between 1970 and 1980 was relatively weak. Between 1980 and 2000, predominance of the Muslim population was associated with steadily increasing aid inflows. Since 2000, this impact stabilized at 0.85 percent.

\section{Does Terrorism Lead to a Diversion of Aid?}

To account for aid diversion (i.e., crowding out of the aid flows unrelated to security since the U.S. embassy bombings in 1998), the study assessed the relationship between foreign aid commitment to areas that are pivotal for a successful counterterrorism strategy and the aid that flows to other countries that do not belong to this group. The dynamic fixed-effects estimator indicates the 


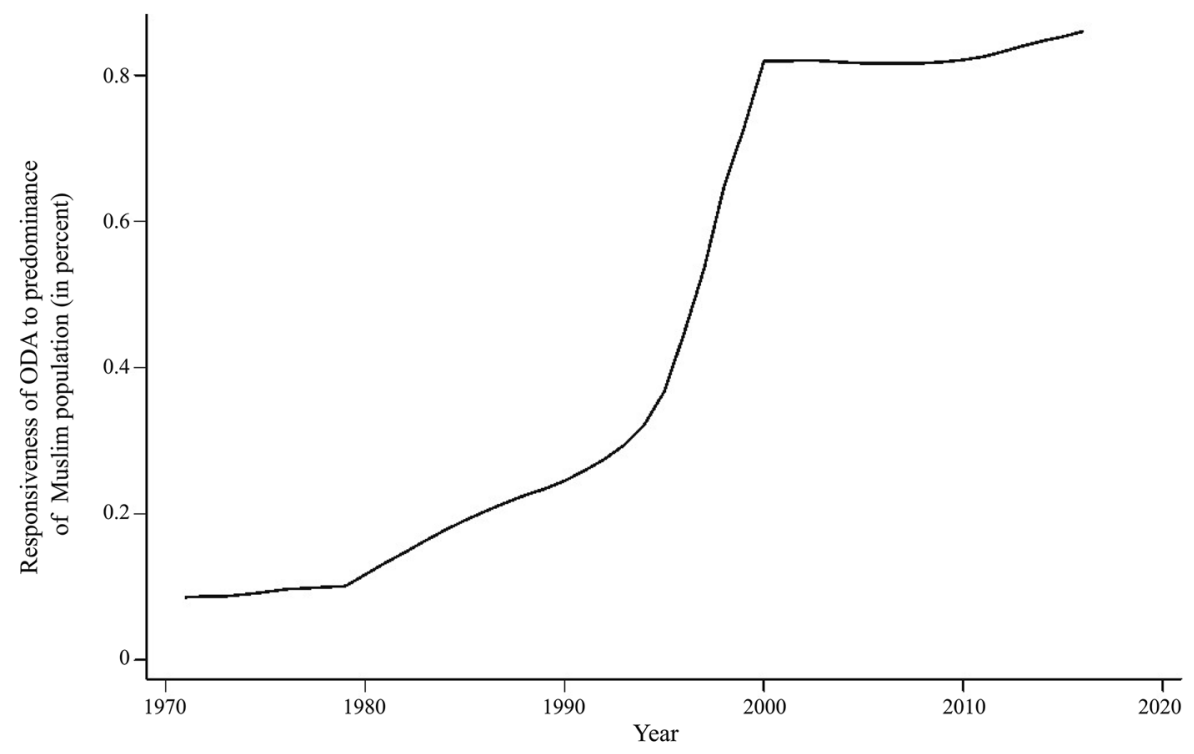

Fig. 3 The predominance of the Muslim population and foreign aid, 1970-2016. Source: Author's calculations based on data from OECD (2019).

existence of statistically significant, but rather weak, diversion bias in the short run, whereby the total OECD bilateral aid for the respective country in the respective year served as the dependent variable, and aid to countries with very high terrorism incidence (i.e., Afghanistan, Iraq, Syria, and Pakistan) served as the independent variable (Online Supplemental Appendix Table 7). The long-run coefficient of the estimator is also very small, but positive. This indicates that in the long run, more aid to the jurisdictions with high terrorism incidence does not lead to long-term divergence of aid from politically stable to terrorism-ravaged regions, but rather to a weak increase in aid to developing areas with low terrorism incidence.

\section{Concluding Remarks}

The present inquiry re-addressed the nexus between terrorism incidents and foreign aid action of the rich OECD member states during the fourth religious wave of modern terrorism. Despite the prognosis of Rapoport that the fourth wave would diminish by 2025 , almost 16 years after this prognosis, it now seems that religiously motivated terrorism will not cease to pose serious risks to the globalization-oriented architecture of international relations over the coming two to three decades. In combination with the conjecture of securitization of foreign aid, this raises a justified critique of foreign aid as a central instrument of international development policy. Does securitization of foreign aid disqualify aid as a tool against underdevelopment? 
Nevertheless, the proposed differential game theory model suggests that increasing the importance of security issues (i.e., the securitization of allocation of international aid) does not automatically imply less development aid. On the contrary, doubling as an indicator for underdevelopment, terrorism incidents catalyzed aid over the fourth wave of modern terrorism and especially during the War-on-Terror phase. More aid for the regions with a high prevalence of terrorism incidents does not lead to less aid for the remaining developing and transition economies. Quite the contrary, the War on Terror led to an overall increase in international aid. By foregrounding the overarching security risks of underdevelopment, the surge of terrorism catalyzed foreign aid action, without any significant repercussions on the frequency of terrorism incidents. Hence, securitization of aid, as confirmed by the comprehensive econometric analysis, is not an impediment, but rather a catalyst of economic development.

Acknowledgements I thank Wilhelm Loewenstein from Ruhr-University Bochum and Kamiar Mohaddes from Cambridge University for inspiring me to conduct this survey, their insightful suggestions and constructive critique. I am also grateful to Gabriele Bäcker from Ruhr-University Bochum, the managing editor, and two anonymous reviewers for their fruitful comments.

Funding Open Access funding enabled and organized by Projekt DEAL.

Open Access This article is licensed under a Creative Commons Attribution 4.0 International License, which permits use, sharing, adaptation, distribution and reproduction in any medium or format, as long as you give appropriate credit to the original author(s) and the source, provide a link to the Creative Commons licence, and indicate if changes were made. The images or other third party material in this article are included in the article's Creative Commons licence, unless indicated otherwise in a credit line to the material. If material is not included in the article's Creative Commons licence and your intended use is not permitted by statutory regulation or exceeds the permitted use, you will need to obtain permission directly from the copyright holder. To view a copy of this licence, visit http://creativecommons.org/ licenses/by/4.0/.

\section{References}

Abadie, A. (2006). Poverty, political freedom, and the roots of terrorism. American Economic Review, 96(2), 50-56.

Alesina, A., \& Dollar, D. (2000). Who gives foreign aid to whom and why? Journal of Economic Growth, $5,33-63$.

Apodaca, C. (2017). Foreign aid as foreign policy tool. Oxford Research Encyclopedia of Politics. Published Online at: https://doi.org/10.1093/acrefore/9780190228637.013.332

Bandyopadhyay, S., Sandler, T., \& Younas, J. (2011). Foreign aid as counterterrorism policy. Oxford Economic Papers, 63(3), 423-447.

Beenstock, M. (1980). Political econometry of official development assistance. World Development, 8(2), 137-144.

Bird, G. (1999). The political economy of foreign aid: Fatigue or regeneration? Zagreb International Review of Economics and Business, 2(2), 1-24.

Blanchard, C. M., \& Prados, A. B. (2007). Saudi Arabia: Terrorist Financing Issues. Congressional Research Service Report for Congress. Order Code RL32499. Available at: https://ntrl.ntis.gov/ NTRL/dashboard/searchResults/titleDetail/ADA468060.xhtml

Boutton, A. (2016). Of terrorism and revenue: Why foreign aid exacerbates terrorism in personalist regimes. Conflict, Management and Peace Science, 36(4), 359-384.

Brown, S., Grävingholt, J., \& Raddatz, R. (2011). The Securitization of Foreign Aid: Trends, Explanations and Prospects. Chapter 11 in: Brown, S., \& Grävingholt, J. The Securitization of Foreign Aid. Basingstroke, UK and New York: Palgrave Macmillan, 237-255. 
Cavalcanti, T. V. de. V., Mohaddes, K., \& Raissi, M. (2011). Does oil abundance harm growth? Applied Economics Letters, 18(12), 1181-1184.

Chudik, A., \& Pesaran, M. H. (2015). Common correlated effects estimation of heterogenous dynamic panel data models with weakly exogenous regressors. Journal of Econometrics, 188(2), 393-420. https://doi.org/10.1016/j.jeconom.2015.03.007

CIA. (1961). Foreign Aid First Aid. CREST General CIA Reports CIA-RDP70-00058R000200120035-8. Available at: https://www.cia.gov/readingroom/document/cia-rdp70-00058r000200120035-8

CIA. (1965). Foreign Aid and Foreign Policy. CREST General CIA Reports 0000969808. Available at: https://www.cia.gov/readingroom/document/0000969808

CIA. (1968). Aid and Trade Activities of Communist Countries in Less Developed Areas of the Free World, 1968. CREST General CIA Reports CIA-RDP92B01090R000400010026-5. Available at: https://www.cia.gov/readingroom/document/cia-rdp92b01090r000400010026-5

CIA. (1970). Soviet Foreign Aid Loses Momentum. Special Report Weekly Review. CREST General CIA Reports CIA-RDP08S01350R000602100001-8. Available at: https://www.cia.gov/readingroom/ document/cia-rdp08s01350r000602100001-8

CIA. (1974). Security - US Agency for International Development (AID). CREST General CIA Reports CIA-RDP80M0182A000100280006-9. Available at: https://www.cia.gov/readingroom/document/ cia-rdp80m01082a000100280006-9

CIA. (1975). Intelligence Report - Economic Aid to the Less Developed Countries, 1974. CREST General CIA Reports CIA-RDP86T00608R000500200010-5. Available at: https://www.cia.gov/readingroom/ document/cia-rdp86t00608r000500200010-5

CIA. (1976). Bush vows CIA aid against terrorists. CREST General CIA Reports CIA-RDP8801315R000200220025-5. Available at: https://www.cia.gov/readingroom/document/cia-rdp8801315r000200220025-5

CIA. (1984). Smaller Gulf States: Cutting Back Foreign Aid. CREST General CIA Reports CIARDP85T00314R000200130002-5. Available at: https://www.cia.gov/readingroom/document/ciardp85t00314r000200130002-5

CIA. (1985a). The Soviet response to instability in West Africa. CREST General CIA Reports CIARDP86T00591R000300440002-2. Available at: https://www.cia.gov/readingroom/document/ciardp86t00591r000300440002-2

CIA. (1985b). Statement of Nathan M. Adams Senate Joint Foreign Relations \& Judiciary Committee Hearings on Terrorism. Sanitized Copy Approved for Release 2010/10/14. CREST General CIA Reports CIA-RDP87B00858R000600940032-2 OLL 85-1501. Available at: https://www.cia.gov/ readingroom/document/cia-rdp87b00858r000600940032-2

CIA. (1986). Indications of instability in Soviet-supported Third World regimes. CREST General CIA Reports CIA-RDP87T00685R000300540002-6. Available at: https:/www.cia.gov/readingroom/ document/cia-rdp87t00685r000300540002-6

Dorfman, R. (1969). An economic interpretation of optimal control theory. American Economic Review, 59(5), 817-831.

Drakos, K., \& Gofas, A. (2006). The devil you know but are afraid to face: Underreporting bias and its distorting effects on the study of terrorism. Journal of Conflict Resolution, 50(5), 714-735.

Dreher, A., \& Fuchs, A. (2011). Does terror increase aid? Public Choice, 149, 337-363.

Dudley, L., \& Montmarquette, C. (1976). A model of the supply of bilateral aid. The American Economic Review, 66(1), 132-142.

Duffield, M. (2002). Social reconstruction and the radicalization of development: Aid as a relation of global liberal governance. Development and Change, 33(5), 1049-1071. https://doi.org/10.1111/ 1467-7660.t01-1-00260.

Duffield, M. (2005). Global Governance and the New Wars. The Merging Development and Security. London \& New York: Zed Books.

Freeman, M., \& Ruehsen, M. (2013). Terrorism financing methods: An overview. Perspectives on Terrorism, 7(4), 5-26.

Fulbright, J. W. (1965). Foreign Aid? Yes, but with a New Approach. New York Times Magazine, March 21, 1965, Section SM, 102-107.

Gaibulliev, K., \& Sandler, T. (2019). What we have learned about terrorism since 9/11. Journal of Economic Literature, 57(2), 275-328.

Getlein, F. (1973). The Failure of Foreign Aid. Washington Star, May $2^{\text {nd }}$. CREST General CIA Reports CIA-RDP88-01365R000300210069-9. Available at: https://www.cia.gov/readingroom/document/ cia-rdp88-01365r000300210069-9 
Gupta, D. K. (2011). Waves of international terrorism: An explanation of the process by which ideas flood the world. In Terrorism, Identity and Legitimacy, Rosenfeld (ed.). Routlege: New York.

Hamilton, L. H. (1982). Foreign Aid's Purpose. Document Release Date: November 13, 2007. Document Number (FOIA) /ESDN (CREST): CIA-RDP88B00443R001103940017-9. Available at: https:// www.cia.gov/readingroom/document/cia-rdp88b00443r001103940017-9

Hoeffler, A., \& Outram, V. (2011). Need, merit, or self-interest - What determines the allocation of aid. Review of Development Economics, 15(2), 237-250.

Hoel, M. (1978). Distribution and growth as a differential game between workers and capitalists. International Economic Review, 19(2), 335-350.

Khasbulatov, R. (1998). The World Economy. Moscow: Knorus.

Lancaster, K. (1973). The dynamic inefficiency of capitalism. Journal of Political Economy, 81(5), 1092-1109.

Lancaster, C. (2006). Foreign Aid: Diplomacy, Development, Domestic Politics. Chicago: University of Chicago Press.

Lee, C. Y. (2016). Oil and terrorism: Uncovering the mechanisms. Journal of Conflict Resolution, 62(5), 903-928.

Lee, J., \& Robinson, P. M. (2015). Panel nonparametric regression with fixed effects. Journal of Econometrics, $188(2), 346-362$.

Li, D., Chen, J., \& Gao, J. (2011). Nonparametric time-varying coefficient panel data models with fixed effects. Econometrics Journal, 14(3), 387-408.

Maizels, A., \& Nissanke, M. K. (1984). Motivations for aid to developing countries. World Development, 12(9), 879-900.

McConnon, E. (2019). Risk and the Security-Development Nexus. The Policies of the US, the UK and Canada. Rethinking International Development Series. Cham, Switzerland: Palgrave Macmillan.

McKinley, R. D., \& Little, R. (1979). The US aid relationship: A test of the recipient need and the donor interest models. Political Studies, 27(2), 236-250.

Miller, E., LaFree, G., \& Dugan, L. (2020). Global Terrorism Database (GTD). Available at: http://www. start.umd.edu/gtd/

Mohaddes, K., \& Raissi, M. (2017). Do sovereign wealth funds dampen the negative effects of commodity price volatility? Journal of Commodity Markets, 8, 18-27.

Mosley, P. (1985). Towards a predictive model of overseas aid expenditures. Scottish Journal of Political Economy, 32(1), 1-19.

Narayan, S., \& Narayan, P. K. (2004). Determinants of demand for Fiji's exports: An empirical investigation. The Developing Economies, 42(1), 95-112.

Nielsen, M. Ø. (2007). Local Whittle analysis of stationary fractional cointegration and the implied-realized volatility relation. Journal of Business \& Economic Statistics, 25(4), 427-446.

OECD. (2019). Net ODA (indicator). https://doi.org/10.1787/33346549-en (Accessed 21 February 2019)

Oxfam. (2011). Whose Aid is It Anyway? Politicalizing Aid in Conflicts and Crises. Oxfam Briefing Paper No. 145. Available at: https://policy-practice.oxfam.org/resources/whose-aid-is-it-anywaypoliticizing-aid-in-conflicts-and-crises-121669/

Paddock, W., \& Paddock, E. (1973). We Don't Know. Ames, Iowa: Iowa State University Press.

Pedroni, P. (2001). Fully Modified OLS for heterogeneous cointegrated panels. In: Baltagi, B.H., Fomby, T.B. \& Carter Hill, R. (Ed.). Nonstationary Panels, Panel Cointegration, and Dynamic Panels (Advances in Econometrics, Vol. 15). Bingley: Emerald Group Publishing Limited, 93-130. https:// doi.org/10.1016/S0731-9053(00)15004-2

Pesaran, M. H., \& Smith, R. (1995). Estimating long-run relationships from dynamic heterogenous panels. Journal of Econometrics, 68(1), 79-113.

Pesaran, M. H., Shin, Y., \& Smith, R. P. (1999). Pooled mean group estimation of dynamic heterogenous panels. Journal of American Statistical Association, 94(446), 621-634.

Picciotto, R. (2007). Aid and conflict: The policy coherence challenge. Conflict, Security \& Development, $4(3), 543-562$.

Pupavac, V. (2010). The consumerism-development-security nexus. Security Dialogue, 41(6), 691-713.

Rapoport, D. (2004). The Four Waves of Modern Terrorism. In A. Cronin \& J. Ludes (Eds.), Attacking Terrorism. (pp. 46-73). Washington, DC: Georgetown University Press.

Rennack, D. E., \& Chesser, S. G. (2011). Foreign Assistance Act of 1961: Authorizations and Corresponding Appropriations. Congressional Research Service 7-5700. R-40087. Available at: https:// fas.org/sgp/crs/row/R40089.pdf 
Sörensen, J. S., \& Söderbaum, F. (2012). Introduction - The End of the Development-Security Nexus? Development Dialogue, 53, 7-19.

Stern, M., \& Öjendal, J. (2010). Mapping the security-development nexus: Conflict, complexity, cacophony, convergence? Security Dialogue, 41(1), 5-29.

Stone, R. W. (2010). Buying Influence: Development Aid between Cold War and War on Terror. Rochester, NY: University of Rochester Press.

Toda, H. Y., \& Yamamoto, T. (1995). Statistical inference in vector autoregressions with possibly integrated processes. Journal of Econometrics, 66(1-2), 225-250.

Tuman, J., Strand, J., \& Shirali, M. (2017). Foreign policy alignment with the War on Terror: The case of Japan's Foreign aid program. Journal of East Asian Studies, 17(3), 343-354.

Walls, E. (2017). Waves of Modern Terrorism: Examining the Past and Predicting the Future. Washington: Georgetown University Press. Available at: https://repository.library.georgetown.edu/bitstream/ handle/10822/1043900/Walls_georgetown_0076M_13610.pdf?sequence=1\&isAllowed=y

World Bank. (2018). World Development Indicators. Available at: https://databank.worldbank.org/source/ world-development-indicators

Younas, J. (2008). Motivation for bilateral aid allocation: Altruism or trade benefits. European Journal of Political Economy, 24(3), 661-674

Publisher's Note Springer Nature remains neutral with regard to jurisdictional claims in published maps and institutional affiliations. 